\title{
Effect of single and multiple pregnancies on performance of primiparous and multiparous cows
}

\author{
A. Sawa, M. Bogucki, and M. Głowska \\ University of Technology and Life Sciences in Bydgoszcz, Faculty of Animal Breeding and Biology, \\ Department of Cattle Breeding, Mazowiecka 28, 85-084 Bydgoszcz, Poland \\ Correspondence to: A. Sawa (sawa@utp.edu.pl)
}

Received: 5 June 2014 - Accepted: 30 October 2014 - Published: 4 March 2015

\begin{abstract}
Data on 393002 parturitions and performance in the following production cycle were collected from the SYMLEK database for 145457 Polish Holstein-Friesian cows representing the active population in the Pomorze and Kujawy regions. The animals first calved during 2000-2012 and were used or culled by the end of 2013. GLM and FREQ procedures of the SAS package were used for the statistical calculations. The frequency of twin and triplet births depended on the cow's age (0.64\% in primiparous and $2.88 \%$ in multiparous cows), calving season (1.79\% in winter, $2.41 \%$ in summer), previous lactation milk yield (increase of 2.15 to $3.73 \%$ with increasing milk production level), and year of calving of primiparous cows (increase from $0.43 \%$ during 2000-2003 to 0.78\% during 2010-2012). Dams of twins were superior to dams of singles in terms of milk yield, but a significant difference was manifest only in multiparous cows. Despite the higher perinatal mortality of the twins and triplets (especially those born to primiparous cows), multiple pregnancy resulted in a greater number of calves born compared to single pregnancy. A negative effect of multiple pregnancies was a decrease in fertility, especially in multiparous cows (e.g. calving interval was longer by 18 days, reproductive rest period by 9 days, and service period by 10 days, while services per conception increased by 0.15 ). In addition, twin pregnancy (especially in heifers) and triplet pregnancy (especially in cows) considerably decreased chance of survival until the next calving.
\end{abstract}

\section{Introduction}

In female cattle (Bos taurus), multiple pregnancies are relatively rare and result in the birth of more calves, most often two (Komisarek and Dorynek, 2002). The natural frequency of twin parturitions in cattle ranges from 0.5 to $4 \%$ depending on many genetic and environmental factors (Fricke, 2001; Fitzgerald et al., 2014; Sawa et al., 2012). Echternkamp and Gregory (2002) obtained around 50\% of multiple pregnancies after selecting cows for increased frequency of multiple ovulations between 1981 and 2001. Holstein-Friesian is among the breeds considered more likely to experience multiple ovulations (Fitzgerald et al., 2014).

Issues related to multiple pregnancies in dairy cattle are important for both veterinary and zootechnical practice, and also have an economic aspect. Therefore, the available literature includes works that are diagnostic, clinical, and breeding in nature. However, opinions concerning twin pregnancy in dairy farming are divided. Most often attention is given to the negative consequences of twin pregnancy, because economic profit does not increase despite the greater number of calves born, and because twin births often involve costs (De Rose, 1991) associated with placental retention, metritis, longer service period and calving interval, ketosis, higher calf mortality, lower birth weight of calves, greater incidence of pregnancy loss, smaller number of fertile heifers for herd replacement, and decreased milk yield (Echternkamp and Gregory, 1999a; Fitzgerald et al., 2014; Nielen et al., 1989). Reduced milk yield may account for $40-52 \%$, and increased calf mortality for $18 \%$, of all costs associated with multiple pregnancy (Beerepoot et al., 1992; Echternkamp and Gregory, 1999a).

The objective of the study was to analyse the effect of single and multiple pregnancies on the milk and reproductive performance of primiparous and multiparous cows, based 
Table 1. Effect of some factors on percentage of single and multiple births in calves.

\begin{tabular}{|c|c|c|c|c|c|c|}
\hline & & & & Jumber & births & \\
\hline $\mathrm{Fac}$ & & & General & Single & Twin & Triplet \\
\hline & & & $N$ & $\%$ & $\%$ & $\%$ \\
\hline To & & & 393002 & 97.95 & 2.03 & 0.01 \\
\hline Pregnancy number & $\chi^{2}=2763^{*}$ & 1 & 145457 & 99.36 & 0.64 & 0.00 \\
\hline & & $\geq 2$ & 247545 & 97.13 & 2.86 & 0.02 \\
\hline Calving season & $\chi^{2}=106^{*}$ & III-V & 95361 & 97.96 & 2.02 & 0.02 \\
\hline & & VI-VIII & 97980 & 97.59 & 2.40 & 0.01 \\
\hline & & IX-XI & 95856 & 98.06 & 1.93 & 0.01 \\
\hline & & XII-II & 103805 & 98.20 & 1.79 & 0.00 \\
\hline $\mathrm{Kg}$ milk in previous lactation & $\chi^{2}=270^{*}$ & $<6000$ & 63353 & 97.85 & 2.14 & 0.01 \\
\hline & & $6000-7999$ & 78303 & 97.27 & 2.71 & 0.01 \\
\hline & & 8000-9999 & 55330 & 96.87 & 3.13 & 0.01 \\
\hline & & $\geq 10000$ & 50016 & 96.28 & 3.70 & 0.03 \\
\hline Year of calving of primiparous & ws $\chi^{2}=51^{*}$ & 2000-2003 & 42136 & 99.57 & 0.43 & 0.00 \\
\hline & & 2004-2006 & 34630 & 99.33 & 0.67 & 0.00 \\
\hline & & 2007-2009 & 34453 & 99.27 & 0.73 & 0.00 \\
\hline & & 2010-2012 & 34235 & 99.22 & 0.77 & 0.01 \\
\hline
\end{tabular}

* Significant at $P \leq 0.1$.

on extensive material obtained from performance testing of cows in the Kujawsko-Pomorskie province (around $10 \%$ of the national population of performance-tested cows).

\section{Material and methods}

Material for the study was collected from the SYMLEK database and provided information on 393002 parturitions as well as milk and reproductive performance in the following production cycles of 145457 Polish Holstein-Friesian cows representing the active population in the Pomorze and $\mathrm{Ku}$ jawy regions. The animals first calved during 2000-2012 and were used or culled by the end of 2013.

Analysis of variance (SAS, 2013; SAS Institute Inc., Cary, NC, USA) was used to determine the effect of type of birth (single, twin, triplet) on subsequent milk performance (days of milking, kilograms of milk), reproductive performance (calving interval, reproductive rest period, service period, number of inseminations, first insemination success), and number of calves born alive. Significant differences were analysed with the Scheffe test (SAS, 2013). The proportion of primiparous and multiparous cows surviving until the next calving was also calculated in relation to the type of birth (single, twin, triplet).

A chi-square test of independence (SAS, 2013) was used to analyse the frequency of single, twin, and triplet births depending on
- age (heifer, cow);

- season of calving (March-May, June-August, September-November, December-February);

- for cows, milk yield in the previous lactation $(<6000 \mathrm{~kg}$, $6000-7999 \mathrm{~kg}, 8000-9999 \mathrm{~kg}$, and $\geq 10000 \mathrm{~kg}$ milk);

- for heifers, age at first calving ( $<24$ months, 24-28 months, > 28 months) and year of calving (2000-2003, 2004-2006, 2007-2009, and 2010-2012).

The chi-square test of independence (SAS, 2013) was also used to determine the effect of type of birth (single, twin, triplet) on the course of calving (calving ease), coded by SYMLEK as follows: unassisted (natural, without human intervention), easy assist, difficult assist (requiring higher than normal force), and dystocia (surgical intervention, injury to the cow or calf, embryotomy, caesarean section).

\section{Results and discussion}

During the period under analysis, twin births accounted for $2.03 \%$ and triplet births for $0.01 \%$ of all calvings in the studied population (Table 1). Studies conducted in Poland indicate that twins account for 1 to $4 \%$ of calves born (Kuźma and Kuźma, 1994; Sawa et al., 2012; Skrzypek et al., 1989). In a North American study of 1.3 million calvings, twin pregnancies accounted for $5 \%$ (Johanson et al., 2001). According to Des Coteaux et al. (2010) and López-Gatius and Hunter 
(2005), twin pregnancies are estimated to form about $10 \%$ of all pregnancies in dairy cattle, but are much less frequent in beef cattle.

Among the experimental factors, the age of cows had the strongest effect on the incidence of multiple pregnancies (Table 1). Like in the studies by other authors (Gregory et al., 1990a; Hossein-Zadeh et al., 2008; Komisarek and Dorynek, 2002; Sawa et al., 2012; Silva del Río et al., 2007), we showed multiple pregnancies to be much more frequent in multiparous cows than in heifers. Each successive lactation increases the probability of multiple ovulations (Fricke, 2001), and the number of twin births increases linearly with the frequency of double ovulation (Fricke and Wiltbank, 1999; Ryan and Boland, 1991). The incidence of twin pregnancies increases from $1 \%$ for primiparous cows to around $10 \%$ in successive lactations. Twin pregnancies show the highest increase between the first and second lactation, after which their incidence increases to a lesser extent (Fricke, 2001). The reason for the smaller number of twin births in primiparous cows is an underdeveloped uterus, which increases embryo mortality. Total uterine area in heifers and young cows is insufficient to maintain several embryos (Grunert et al., 1999). Attention is also drawn to the fact that heifers show increased mortality of one of the fetuses in multiple pregnancy, due to the increased protein and energy requirement from the still-developing body of the dam and twin fetuses (Kuźma and Kuźma, 1994).

Analysis of the incidence of multiple pregnancies depending on the season of calving showed that they were most frequent in summer (2.41\%), followed by spring (2.04) and autumn (1.79). Other authors (Frick, 2001; Gregory et al., 1996; Komisarek and Dorynek, 2002; Silva del Río et al., 2007) have also reported that a high proportion of twin births take place during the spring and summer months. Better quality of feeds offered in the autumn and optimum temperature (absence of heat stress) contribute to multiple ovulations in the cows. A US study showed the frequency of twin births to be $8.3 \%$ from April to June, $9.7 \%$ from July to September, $5.2 \%$ from October to December, and $2.3 \%$ from January to March (Silva del Río et al., 2006). Other studies reported most multiple births to occur between April and September in the Netherlands (Nielen et al., 1989) and between May and July in Saudi Arabia (Ryan and Boland, 1991).

The proportion of multiple pregnancies was found to increase significantly $(P \leq 0.01)$ with the increasing production level of the cows. Higher milk yield is conducive to double ovulations, which, in turn, affects the incidence of twin pregnancies (Max, 2011). In cows with high milk yields, double ovulation is 3 times as frequent as in animals with medium and low milk production levels (Fricke and Wiltbank, 1999). Multiple ovulations in high-yielding cows is caused by intensive feeding (Fricke, 2001). According to Komisarek and Dorynek (2002) and Fricke and Wiltbank (1999), high-energy feeds offered in the first stage of lactation contribute to double ovulations.
For present-day breeders, it is important to note that the proportion of twin pregnancies increased significantly $(P \leq$ 0.01 ) from $0.43 \%$ in heifers calving during 2000-2003 to $0.77 \%$ in heifers that calved during 2010-2012.

This is likely associated with increased production levels of the active population, because the milk yield of primiparous cows that calved in 2000 was $5969 \mathrm{~kg}$ compared to $8215 \mathrm{~kg}$ for primiparous cows that calved in 2012. According to Des Coteaux et al. (2010) and López-Gatius and Hunter (2005), there is a positive correlation between milk yield and frequency of multiple pregnancies. An analysis of 91008 calvings from 1974 to 1985 by Stolzenburg (1988) showed that twins were born much more frequently in the HolsteinFriesian compared to the Black-and-White breed.

Analysis of the present results shows a non-significant tendency for the proportion of twin pregnancies to increase with the older age of the heifers at first calving. Our results demonstrate that single pregnancy was around 2 days shorter in heifers than in cows, whereas twin pregnancy was 276 days regardless of cow's age (Table 2). When analysing the production efficiency of Montbeliard and Polish Holstein-Friesian cattle, Gołębiewski (2010) concluded that heifers were characterized by a shorter duration of pregnancy than cows.

In heifers, the duration of twin pregnancy was 2.8 days shorter, and that of triplet pregnancy was 3.3 days shorter than single pregnancy length; in cows, these values were 4.6 and 6.3 days shorter, respectively (Table 2). These results conform to the findings of other authors who reported that the duration of pregnancy in cows expecting twins is predicted to be shorter by 5 to 7 days (Echternkamp and Gregory, 1999a; Kirkpatrick, 2002). The shorter duration of pregnancy is probably the main reason for the low birth weight of twin calves (Gregory et al., 1996). The shorter duration of twin pregnancy is conducive to placental retention in females (Echternkamp and Gregory, 1999a; Kuźma and Kuźma, 1994; Max, 1996; Nielen et al., 1989). To reduce the negative effects of premature births, cows expecting twins should be given proper care while monitoring the course of pregnancy and feeding diets with sufficient energy and nutrients to maintain a greater number of fetuses to term (Atashi et al., 2012; Kirkpatrick, 2002).

Difficult births (requiring higher than normal force) and dystocia (requiring veterinary assistance) ranged from $4.31 \%$ (single pregnancy) to $20 \%$ (triplet pregnancy) in heifers, and from $1.67 \%$ (single pregnancy) to $18.42 \%$ (triplet pregnancy) in cows (Table 3). Other authors also attribute birthing difficulties to the number of previous lactations (Gaafar et al., 2011) and number of fetuses (Gaafar et al., 2011; Gregory et al., 1990b; Kuźma and Kuźma, 1994; Sawa et al., 2012). Kuźma and Kuźma (1994) report that pregnancy loss and premature and difficult births are twice as frequent in twin-producing cows as in cows with single pregnancies, attributing this, among other things, to a poorly balanced ration during the dry period. According to Gregory 
Table 2. Milk and reproductive performance of primiparous and multiparous cows in a productive cycle after giving birth to single, twin, and triplet calves.

\begin{tabular}{|c|c|c|c|c|c|c|}
\hline \multirow{3}{*}{ Performance trait } & \multicolumn{3}{|c|}{ Primiparous } & \multicolumn{3}{|c|}{ Multiparous } \\
\hline & \multicolumn{3}{|c|}{ Type of pregnancy } & \multicolumn{3}{|c|}{ Type of pregnancy } \\
\hline & Single & Twin & Triplet & Single & Twin & Triplet \\
\hline$N$ & 144526 & 926 & 5 & 240439 & 7068 & 38 \\
\hline Days in milk & 361 & 363 & 434 & $334^{\mathrm{A}}$ & $339^{\mathrm{A}}$ & 299 \\
\hline Kg milk per lactation & 7519 & 7703 & 8893 & $7676^{\mathrm{A}}$ & $7996^{\mathrm{A}}$ & 7036 \\
\hline Calving interval, days & $430^{\mathrm{a}}$ & $439^{\mathrm{a}}$ & 452 & $422^{\mathrm{A}}$ & $440^{\mathrm{A}}$ & 455 \\
\hline Rest period, days & $95^{\mathrm{a}}$ & $101^{\mathrm{a}}$ & 98 & $93^{\mathrm{A}}$ & $102^{\mathrm{A}}$ & 108 \\
\hline Service period, days & 54 & 56 & 70 & $47^{\mathrm{A}}$ & $57^{\mathrm{A}}$ & 66 \\
\hline Insemination index & 2.17 & 2.18 & 3.00 & $2.05^{\mathrm{A}}$ & $2.20^{\mathrm{A}}$ & 2.60 \\
\hline First insemination success, $\%$ & 44.1 & 41.5 & 25.0 & 47.6 & 41.6 & 33.3 \\
\hline Length of pregnancy, days & $278.8^{\mathrm{A}}$ & $276,0^{\mathrm{A}}$ & 275.5 & $280.7^{\mathrm{A}}$ & $276.1^{\mathrm{A}}$ & $274.4^{\mathrm{B}}$ \\
\hline Number of calves born alive & $0.92^{\mathrm{AB}}$ & $1.79^{\mathrm{A}}$ & $1.80^{\mathrm{B}}$ & $0.95^{\mathrm{AB}}$ & $1.85^{\mathrm{AC}}$ & $2.55^{\mathrm{BC}}$ \\
\hline Proportion $(\%)$ of production cycles that ended in calving & 72.2 & 67.2 & 80 & 58.3 & 51.3 & 39.5 \\
\hline
\end{tabular}

ABC Significant at $P \leq 0.1{ }^{\text {a }}$ significant at $P \leq 0.5$.

Table 3. Course of parturition depending on the number of calves born.

\begin{tabular}{|c|c|c|c|c|c|c|}
\hline \multirow[t]{2}{*}{ Age of cows } & \multirow{2}{*}{$\begin{array}{l}\text { Type of } \\
\text { pregnancy }\end{array}$} & \multicolumn{5}{|c|}{ Course of parturition, $\%$} \\
\hline & & $N$ & Unassisted birth & Easy & Difficult & Very difficult \\
\hline \multirow[t]{3}{*}{ Primiparous $\chi^{2}=14^{*}$} & Single & 144255 & 25.84 & 69.85 & 4.12 & 0.19 \\
\hline & Twin & 926 & 24.19 & 69.33 & 6.26 & 0.22 \\
\hline & Triplet & 5 & 0.00 & 80.00 & 20.00 & 0.00 \\
\hline \multirow[t]{3}{*}{ Multiparous $\chi^{2}=444^{*}$} & Single & 240436 & 40.09 & 58.24 & 1.58 & 0.09 \\
\hline & Twin & 7068 & 30.65 & 65.05 & 4.05 & 0.25 \\
\hline & Triplet & 38 & 15.79 & 65.79 & 18.42 & 0.00 \\
\hline
\end{tabular}

* Significant at $P \leq 0.5$.

et al. (1990b), frequency of assistance was $35 \%$ for twincalving cows and $23 \%$ for single-calving cows. Gregory et al. (1996) suggests that compared to single pregnancies, calving assistance is required twice as frequently for twin pregnancies, and most complications are due to abnormal position of one or two fetuses.

Similar to other authors (Echternkamp and Gregory, 1999b; Mostafa, 2009; Silva del Río et al., 2007), we showed that multiple pregnancy contributes $(p \leq 0.01)$ to increased calf mortality, which was higher when calves were born of the first pregnancy. Other authors (Echternkamp and Gregory, 1999b) also report that calf mortality following triplet births is greater than after twin births, and higher mortality is observed in twins born to primiparous cows (Berry et al., 1994; Silva del Río et al., 2007). The increased incidence of mortality among twin-born calves may be due to lower birth weight, an earlier calving date, and calving difficulties (Gregory et al., 1996). During the last months of twin pregnancy, cows have an increased risk of fetal death and abortion compared to normal pregnancy (Echternkamp et al.,
2007; Hossein-Zadeh et al., 2008). This phenomenon may result from inadequate ability of the placenta to supply nutrients to two or more fetuses or from hormonal abnormalities (Çobanoğlu, 2010).

When analysing the effect of the type of pregnancy (single, multiple) on the milk yield of primiparous and multiparous cows, we found a significant difference $(P \leq 0.01)$ only for multiparous cows. Among multiparous cows, the milk yield of dams of twins was $320 \mathrm{~kg}$ higher $(P \leq 0.01)$ than that of dams of singles, while dams of triplets had the lowest milk yield.

Other authors show varying results concerning the effect of multiple pregnancies on milk yield in the next lactation. Some studies point to favourable relationships between multiple births and milk yield (Çobanoğlu, 2010). A study from as early as 1974 showed the correlation between the incidence of twin pregnancies and milk yield to be 0.32 for the first and 0.19 for the second lactation (Bar-Anan and Bowman, 1974). Nielen et al. (1989) reported that, during the first 100 days of lactation, cows producing multiple births 
yielded an average of $103 \mathrm{~kg}$ more milk than cows producing single births. A study of the Iranian population of HolsteinFriesian cattle (Hossein-Zadeh, 2010a) revealed that cows that have had multiple births are characterized by a higher 305-day lactation yield on average compared to cows producing single births. According to Fricke (2001), cows producing multiple births have lower milk yields, which the author attributed to metabolic disorders that are a frequent outcome of such births. Likewise, Bicalho et al. (2007) and Mostafa (2009) demonstrated a negative effect of twin pregnancy on the cows' milk yield, which was lowest in females in which one of the twins was stillborn. In an extensive review of the literature, Skrzypek et al. (1989) concluded that the effect of multiple pregnancy on the milk yield of cows is complex and depends on satisfying the pregnant cow's nutrient requirements, the levels of estrogenic hormones, progesterone, placental lactogen and prolactin, and dry period length.

Our results demonstrate that multiple pregnancies have a considerable effect on further reproductive capacity of cows, which is consistent with the findings of other authors (Andreu-Vázquez et al., 2012; Çobanoğlu, 2010; HosseinZedeh, 2010b; Max, 2011). Analysis of fertility in primiparous and multiparous cows showed that it deteriorates after multiple births, and particularly unfavourable values of the fertility parameters were observed for triplet births. In primiparous dams of twins, the reproductive rest period was 6 days longer than in dams of single calves, and in multiparous dams it was 9 days longer. Other authors (Echternkamp and Gregory, 1999b) also note that the period to first oestrus after calving is longer (by as much as 12 days) in cows producing twins, compared to cows with a single calf. Cows that gave multiple births require a greater number of inseminations for successful conception (Çobanoğlu, 2010). We found a similar tendency in the present study, but a statistically significant difference was only found for multiparous cows. According to Andreu-Vázquez et al. (2012), compared to dams of single calves, females that have had multiple pregnancies are less likely to reconceive before 90 days after calving. Importantly, if cows producing a twin pregnancy reconceive, they are more likely to abort than cows producing a single pregnancy (Andreu-Vázquez et al., 2012). Multiple pregnancies also adversely affect the length of calving interval, which was also reported by Çobanoğlu (2010). What is more, differentsex twin pregnancy increases the risk of giving birth to infertile heifers, and it is very important for a dairy herd to produce fertile heifers (Nielen et al., 1989). Many problems associated with a previous multiple pregnancies may make females completely infertile or lead to their deaths as a result of post-parturient complications (Çobanoğlu, 2010).

Twin pregnancy (especially in heifers) and triplet pregnancy (especially in cows) decreased chance of survival until the next calving. Cows that have had multiple births are culled more frequently due to low fertility and reduced milk production (Andreu-Vázquez et al., 2012).
Cow's age, season of calving, milk production in the previous lactation, and year of first calving had a significant $(P \leq 0.01)$ effect on the frequency of twin and triplet births. The consequences of multiple pregnancies in PHF (Polish Holstein-Friesian) cows were considered debatable.

Dams of twins were superior to dams of singles in terms of milk yield, but a significant difference was manifest only by multiparous cows. Despite the higher perinatal mortality of the twins and triplets (especially those born to primiparous cows), multiple pregnancies resulted in a greater number of calves born compared to single pregnancy. A negative effect of multiple pregnancies was a decrease in fertility, especially in multiparous cows (e.g. calving interval was longer by 18 days, reproductive rest period by 9 days, and service period by 10 days, while services per conception increased by 0.15 ). Furthermore, twin pregnancy (especially in heifers) and triplet pregnancy (especially in cows) decreased chance of survival until the next calving. The increased incidence of multiple pregnancies found in 2000-2012 and associated with an increase in cows' milk production level shows that it is necessary to pay special attention to their early diagnosis. This could help reduce the negative consequences of multiple pregnancies.

Edited by: A.-E. Freifrau von Tiele-Winckler

Reviewed by: three anonymous referees

\section{References}

Andreu-Vázquez, C., Garcia-Ispierto, I., Ganau, S., Fricke, P. M., and López-Gatius, F.: Effects of twinning on the subsequent reproductive performance and productive lifespan of highproducing dairy cows, Theriogenology, 78, 2061-2070, 2012.

Atashi, H., Zamiri, M. J., and Sayyadnejad, M. B.: Effect of twinning and stillbirth on the shape of lactation curve in Holstein dairy cows of Iran, Arch. Tierz., 55, 226-233, 2012.

Bar-Anan, R. and Bowman, J. C.: Twinning in Israeli-Friesian dairy herds, Anim. Prod., 18, 109-115, 1974.

Beerepoot, G. M. M., Dykhuizen, A. A., Nielen, M., and Schukken, Y. H.: The Economics of Naturally Occurring Twinning in Dairy Cattle, J. Dairy Sci., 75, 1044-1051, 1992.

Berry, S. L., Ahmadi, A., and Thurmond, M. C.: Periparturient disease on large, dry lot dairies: Interrelationships of lactation, dystocia, calf number, calf mortality, and calf sex, J. Dairy Sci., 77 (abstract), 379, 1994.

Bicalho, R. C., Cheong, S. H., Galvão, K. N., Warnick, L. D., and Guard, C. L.: Effect of twin birth calvings on milk production, reproductive performance, and survival of lactating cows, J. Am. Vet. Med. Assoc., 231, 1390-1397, 2007.

Çobanoğlu, Ö.: Twinning in Cattle: Desirable or Undesirable?, J. Biol. Environ. Sci., 4, 1-8, 2010.

De Rose, E. P. and Wilton, J. W.: Productivity and profitability of twin births in beef cattle, J. Anim. Sci., 69, 3085-3093, 1991.

Des Côteaux, L., Gnemmi, G., and Colloton, J. D.: Practical atlas of ruminant and camelid reproductive ultrasonography, Ames, Iowa, USA, 2010. 
Echternkamp, S. E. and Gregory, K. E.: Effects of twinning on gestation length, retained placenta, and dystocia, J. Anim. Sci., 77, 39-47, 1999a.

Echternkamp, S. E. and Gregory, K. E.: Effects of twinning on postpartum reproductive performance in cattle selected for twin births, J. Anim. Sci., 77, 48-60, 1999b

Echternkamp, S. E. and Gregory, K. E.: Reproductive, growth, feedlot, and carcass traits of twin vs single births in cattle, J. Anim. Sci., 80 (E-Suppl.), E1-E10, 2002.

Echternkamp, S. E., Cushman, R. A., Allan, M. F., Thallman, R. M., and Gregory, K. E.: Effects of ovulation rate and fetal number on fertility in twin-producing cattle, J. Anim. Sci., 85, 3228-3238, 2007.

Fitzgerald, A. M., Berry, D. P., Carthy, T., Cromie, A. R., and Ryan, D. P.: Risk factors associated with multiple ovulation and twin birth rate in Irish dairy and beef cattle, J. Anim. Sci., 92, 966973, 2014.

Fricke, P. M.: REVIEW: Twinning in Dairy Cattle, Prof. Anim. Sci., 17, 61-67, 2001.

Fricke, P. M. and Wiltbank, M. C.: Effect of milk production on the incidence of double ovulation in dairy cows, Theriogenology, 52, 1133-1143, 1999.

Gaafar, H. M. A., Shamiah, S. M., Abu El-Hamd, M. A., Shitta, A. A., and Tag El-Din, M. A.: Dystocia in Friesian cows and its effects on postpartum reproductive performance and milk production, Trop. Anim. Health Prod., 43, 229-234, 2011.

Gołębiewski, M.: [Comparison of performance efficiency of Montbeliarde and Polish Holstein-Friesian dairy cattle], Doctoral thesis, SGGW-AR, Warszawa, Poland, 2010 (in Polish).

Gregory, K. E., Echternkamp, S. E., and Cundiff, L. V.: Effects of twinning on dystocia, calf survival, calf growth, carcass traits, and cow productivity, J. Anim. Sci., 74, 1223-1233, 1996.

Gregory, K. E., Echternkamp, S. E., Dickerson, G. E., Cundiff, L. V., Koch, R. M., and Van Vleck, L. D.: Twinning in cattle: I. Foundation animals and genetic and environmental effects on twinning rate, J. Anim. Sci., 68, 1867-1876, 1990a.

Gregory, K. E., Echternkamp, S. E., Dickerson, G. E., Cundiff, L. V., Koch, R. M., and Van Vleck, L. D.: Twinning in cattle: III. Effects of twinning on dystocia, reproductive traits, calf survival, calf growth and cow productivity, J. Anim. Sci., 68, 3133-3144, 1990 b.

Grunert, E., Berchthold, M., de Kruif, A., and Ahlers, D.: Fertility problems in female cattle, 3. rev. ed., Berlin, Germany, 1999 (in German).

Hossein-Zadeh, N. G.: The effect of twinning on milk yield, dystocia, calf birth weight and open days in Holstein dairy cows of Iran, J. Anim. Physiol. Anim. Nutr., 94, 780-787, 2010a.

Hossein-Zadeh, N. G.: Evaluation of the effect of twin births on the perinatal calf mortality and productive performance of Holstein dairy cows, Arch. Tierz., 53, 256-265, 2010b.
Hossein-Zadeh, N. G., Nejati-Javaremi, A., Miraei-Ashtiani, S. R., and Kohram, H.: An Observational Analysis of Twin Births, Calf Stillbirth, Calf Sex Ratio, and Abortion in Iranian Holsteins, J. Dairy Sci., 91, 4198-4205, 2008.

Johanson, J. M., Berger, P. J., Kirkpatrick, B. W., and Dentine, M. R.: Twinning Rates for North American Holstein Sires, J. Dairy Sci., 84, 2081-2088, 2001.

Kirkpatrick, B. W.: Management of twinning cow herds, J. Anim. Sci., 80 (E-Suppl.), E14-E18, 2002.

Komisarek, J. and Dorynek, Z.: Genetic aspects of twinning in cattle, J. Appl. Genet., 43, 55-68, 2002.

Kuźma, R. and Kuźma, K.: Incidence of multiple births in dairy cows under natural conditions and their effect on parturition, postparturient period and fertility, Prz. Hod., 62, 1-5, 1994 (in Polish).

López-Gatius, F. and Hunter, R. H. F.: Spontaneous reduction of advanced twin embryos: its occurrence and clinical relevance in dairy cattle, Theriogenology, 63, 118-125, 2005.

Max, A.: Twin pregnancy in cattle, Med. Wet., 52, 85-88, 1996 (in Polish).

Max, A.: The fertility of cows after twin parturitions in the herd of high milk yield, Życ. Wet., 86, 618-619, 2011 (in Polish).

Mostafa, A. S.: Twinning in dairy cattle and its effect on milk yield, lactation length, dry period length and calf performance, Bs. Vet. Med. J., 2, 13-18, 2009.

Nielen, M., Schukken, Y. H., Scholl, D. T., Wilbrink, H. J., and Brand, A.: Twinning in dairy cattle: A study of risk factors and effects, Theriogenology, 32, 845-862, 1989.

Ryan, D. P. and Boland, M. P.: Frequency of twin births among Holstein-Friesian cows in a warm dry climate, Theriogenology, 36, 1-10, 1991.

SAS: SAS/STAT 9.4 User's Guide. SAS Institute, Inc., Cary, NC, USA, 2013.

Sawa, A., Bogucki, M., and Krężel-Czopek, S.: Reproduction performance of cows with single, twin and triplet calves, Acta Vet. Brno., 81, 347-352, 2012.

Silva del Río, N., Stewart, S., Rapnicki, P., Chang, Y. M., and Fricke, P. M.: An Observational Analysis of Twin Births, Calf Sex Ratio, and Calf Mortality in Holstein Dairy Cattle, J. Dairy. Sci., 90, 1255-1264, 2007.

Skrzypek, R., Baraniak, R., and Grycz, J.: Influence of twinning on milk yield, reproductive performance and culling rate of cows as well as on the viability of their calves, Zesz. Nauk. AR. w Poznaniu, 38, 83-94, 1989 (in Polish).

Stolzenburg, U.: Twinning rate in the cattle population and importance of breeding value and mating value for twinning in AI bulls, Arch. Tierz., 31, 231-239, 1988. 